\title{
The Determinants of Inclusive Economic Growth in Yogyakarta
}

\author{
Ibnu Hidayat ${ }^{1^{*}}$, Sri Mulatsih ${ }^{2}$, Wiwiek Rindayati $^{3}$ \\ ${ }^{1,2,3}$ Fakultas Ekonomi dan Managemen, Institut Pertanian Bogor, Indonesia \\ 'ibnuhidayat9@gmail.com, ${ }^{2}$ mulatsupardi@gmail.com, ${ }^{3}$ wiwiekrinda@yahoo.com, ${ }^{*}$ corresponding author
}

\begin{abstract}
Inclusive economic growth is related to how economic growth achieved can reduce poverty, income inequality, and unemployment. The purpose of this study is to analyze factors that influence inclusive economic growth in Yogyakarta. This study used panel data from 2011 to 2017. Estimation of the model (simultaneous equations) used the Two-Stage Least Square (2SLS) method. The result of the analysis showed that Factors that have a positive impact on inclusive economic growth are household consumption, exports of service/goods, foreign investment, domestic investment, per capita income, and average length of year of study. Whereas the negative influence is the level of open unemployment and imports of service/goods. An increase in household consumption by $2 \%$ willincrease gross regional domestic product by $1.5 \%$, decrease the open unemployment rate by $3.0 \%$, decrease poverty by $10.7 \%$, and decrease income inequality by $5.5 \%$.
\end{abstract}

Keywords: inclusive economic growth, simultaneous equations, 2SLS

\section{Faktor-Faktor yang Mempengaruhi Pertumbuhan Ekonomi Inklusif di Yogyakarta}

\begin{abstract}
Abstrak
Pertumbuhan ekonomi dikatakan inklusif jika memberi manfaat bagi masyarakat bawah seperti dapat mengurangi kemiskinan, ketimpangan pendapatan, dan pengangguran. Tujuan dari penelitian ini adalah untuk menganalisis faktor-faktor yang mempengaruhi pertumbuhan ekonomi inklusif di Daerah Istimewa Yogyakarta. Penelitian ini menggunakan data panel dari tahun 2011 hingga tahun 2017. Estimasi model (persamaan simultan) menggunakan metode Two Stage Least Square (2SLS). Analisis menunjukkan bahwa faktor-faktor yang memiliki pengaruh positif terhadap pertumbuhan ekonomi inklusif adalah konsumsi rumah tangga, ekspor barang/jasa, investasi asing, investasi domestik, pendapatan perkapita, dan rata-rata lama sekolah. Sedangkan pengaruh negatifnya adalah tingkat pengangguran terbuka dan impor barang/jasa. Peningkatan konsumsi rumah tangga sebesar 2\% akan meningkatkan produk domestik regional bruto sebesar $1.5 \%$, menurunkan tingkat pengangguran terbuka sebesar 3.0\%, menurunkan kemiskinan sebesar $10.7 \%$ dan menurunkan ketimpangan pendapatan sebesar 5.5\%.
\end{abstract}

Kata kunci: Pertumbuhan ekonomi inklusif, persamaan simultan, 2SLS

\section{INTRODUCTION}

Economic growth accompanied by increasing income inequality within a country can cause the gap between the poor and the rich to widen. Increasing inequality will encourage crime from people who feel that the right to live properly is deprived. Therefore, the development target is not sufficient with high economic growth, but it is necessary to ensure that all people enjoy the benefits of this economic growth, including the poor, or what is known as inclusive economic growth (Asian Development Bank, 2011).

Inclusive economic growth in Asia has existed since economic growth was accompanied by a reduction in poverty and inequality (Klasen, 2010). There are several concepts of inclusive economic growth. World Bank (2018) defines inclusive economic 
growth as growth that reduces poverty and ensures economic security for all groups of society. Meanwhile, the Asian Development Bank identifies inclusive economic growth in two strategic focuses, namely sustainable income growth and opportunities that are open to all parties to benefit from economic growth (Ali \& Son, 2007; Ali \& Zhuang, 2007; Klasen, 2010; McKinley, 2010). Lee \& Sissons (2016) emphasize that growth must be able to increase employment for the poor. The definitions described above use the same indicator approach, namely economic growth that can reduce poverty, income inequality, and unemployment rate.

One of the provinces in Indonesia whose economic growth continues to increase is the Special Region of Yogyakarta. This can be seen from the growth rate of the Gross Regional Domestic Product at Constant Prices in 2010 which continued to increase. Growth of Gross Regional Domestic Product at Constant Prices in Yogyakarta reached $4.95 \%$ in 2015 , increased to $5.05 \%$ in 2016 and $5.26 \%$ in 2017 , higher than the Indonesia level in the same period, namely 4.88\% (2015), 5.03\% (2016), and 5.07\% (2017) (Badan Pusat Statistik, 2018).

Increasing economic growth in Yogyakarta has not been matched by improvements in indicators for inclusive economic growth. From the income inequality indicator, the Yogyakarta Gini Ratio figures during the 2015 - 2017 period increased from 0.42 (2015) to 0.43 (2016) and 0.44 (2017). The level of inequality in Yogyakarta was also higher than the Indonesia inequality in the same period, namely 0.40, 0.39, and 0.39. Even in 2018, inequality in Yogyakarta was ranked first with a Gini ratio of 0.44 (Badan Pusat Statistik, 2018).

Poverty indicators show that the poverty rate in Yogyakarta has decreased, but it is still higher than the Indonesia level. In 2015, the poverty rate in Yogyakarta reached 13.16\% (Indonesia 11.13\%) and in 2017 of $11.81 \%$ (Indonesia 9.66\%). Likewise, so is the unemployment indicator. Although lower than the Indonesia level, the unemployment rate in Yogyakarta continues to increase in line with the increase in Gross Regional Domestic Income. In 2016, unemployment in Yogyakarta was 2.72\% (Indonesia 5.61\%), in the following year it increased to 3.02\% (Indonesia 5.50\%), and in 2018, it was 3.06\% (Indonesia 5.13\%) (Badan Pusat Statistik, 2018).

The description above shows that inclusive economic growth has not occurred in Yogyakarta. This study aims to determine the factors that influence inclusive economic growth in Yogyakarta and to formulate policies to increase inclusive economic growth in Yogyakarta.

Empirical studies on inclusive economic growth have been carried out. Research by Sholihah et al. (2018) used the Poverty-Equivalent Growth Rate (PEGR) method to show that economic growth in Indonesia in 2008-2012 has not been inclusive in reducing poverty, inequality, or increasing employment. The same method was used by Azwar (2016) used the Social Mobility Curve method and Poverty-Equivalent Growth Rate (PEGR) shows that the total growth in South Sulawesi has not yet reached inclusive growth. Meanwhile, economic growth, education, and the number of poor people have a negative and significant impact on inclusive growth. The same method was used by Satrio et al. (2019) in West 
Sumatra. Growth in West Sumatra has not been inclusive. Health and education have a positive effect on inclusive growth. Government spending on infrastructure hurts inclusive growth, while economic growth does not affect inclusive growth in West Sumatra.

Anand et al. (2013) used the Social Mobility Curve method to look at inclusive growth and panel data regression to see the factors that influence inclusive growth in developing countries. The results of this research showed that macroeconomic stability, human capital, and structural change were the basis for achieving inclusive growth. The same method was used by Munir \& Ullah (2018) in Pakistan. The results showed that Pakistan had not experienced inclusive growth. The growth in the money supply and domestic credit to the private sector has a significant effect on inclusive growth in Pakistan. This research method was also used by Alekhina \& Ganelli (2020) in ASEAN countries. The results showed that ASEAN countries had not experienced inclusive growth. Fiscal redistribution, female labor force participation, s growth, foreign direct investment inflows, digitization, and savings significantly drive inclusive growth.

\section{METHOD}

This study used panel data covering 5 districts and cities in Yogyakarta Province from 2011 to 2017 period. The data were obtained from the Central Statistics Agency. Simultaneous equation models were used to see the factors that influence inclusive economic growth, consisting of 4 endogenous variables ( 4 structural equations) and 7 predetermined variables. The model is over identified, so it is estimated to use the Two-Stage Least Square (2SLS) method. The 2SLS method was chosen because it can produce consistent, simpler, and easier estimates than other methods (Gujarati \& Porter, 2010).

The model is built based on economic theory and studies of previous studies. The simultaneous equation model for inclusive economic growth is described as follows.

Gross Regional Domestic Product

LnPDRBit $=a_{0}+a_{1}$ LnJTPTit $+a_{2}$ LnKNRTit $+a_{3}$ LnEKSit $+a_{4}$ LnPMADit $+a_{5}$ LnUMRit + $u_{1} i t$.......

Open Unemployment Rate

LnJTPTit $=b_{0}+b_{1} L n P D R B i t+b_{2}$ LnIMRit $+b_{3}$ LnUMRit $+u_{2} i t$

Poverty

KMKit $=c_{0}+c_{1} L n P D R B i t+c_{2} L n P D K P i t+c_{3} L n R L S i t+u_{3} i t$.

Income Inequality

GINit $=d_{0}+d_{1}$ LnPDRBit $+d_{2}$ LnKNRTit $+d_{3}$ LnUMRit $+u_{4} i t$

PDRB: Gross Regional Domestic Product at Constant Prices (Million Rupiah); JTPT: Open Unemployment Rate (Person); KMK: Poverty (Percent); GIN: Gini Ratio Index (01); KNRT: Household Consumption (Million Rupiah); EKS: Exports of Goods/Services 
(Million Rupiah); PMAD: Foreign and Domestic Investment (Million Rupiah); UMR: district/city minimum wage (Rupiah); IMR: Imports of Goods/Services (Million Rupiah); PDKP: Income Per Capita (Million Rupiah); RLS: Average length of year of study (Year); Ln: Natural Logarithm; t: Year; i: District/City; $a_{0}, b_{0}, c_{0}, d_{0}$ : Intercept; $a_{i}, b_{i}, c_{i}, d_{i}$ : Regression coefficient (i $=1,2,3 \ldots \mathrm{n}) ; u_{1}, u_{2}, u_{3}, u_{4}$ : Error.

Each equation is subjected to an $\mathrm{F}$ test and a t-test to determine which explanatory variables (endogenous and predetermined variables) have a significant effect on endogenous variables. The coefficient of determination $\left(\mathrm{R}^{2}\right)$ is used to determine the percentage of endogenous variables that can be explained by explanatory variables (endogenous and predetermined variables).

Simulation analysis is used to determine policies to increase inclusive economic growth in Yogyakarta. Testing the validity of the model uses the root mean squared percentage error (RMSPE) and Theil Inequality Coefficient (U-Theil). RMSPE is the average square of the proportion of the difference in the estimated value with the observed value of an endogenous variable. The smaller the RMSPE value, the more valid the endogenous variable estimate. The maximum $U$ value is one and the minimum is zero. If the $U$ value gets closer to 0 , the endogenous variable estimate is said to be well (Pindyck and Rubinfeld, 1997).

\section{FINDING AND DISCUSSION}

The factors that influence inclusive economic growth were analyzed using the Two-Stage Least Square (2SLS) method and used the Statistical Analysis System/Econometrics and Time Series (SAS/ETS) version 9.4 software by using a linear system procedure (SYSLIN). The results of the analysis are shown in Table 1 . The coefficient of determination $\left(\mathrm{R}^{2}\right)$ of the 4 structural equations ranges from 0.4889 to 0.9918 . This value indicates that the explanatory variables (predetermined variables and endogenous variables) are very good at explaining the diversity of endogenous variables. The value of all $\mathrm{F}$ tests (Prob F-statistic) is smaller than the real level of $1 \%$. In general, the estimation results show that the model meets theoretically meaningful and goodness of fit.

The coefficient of determination $\left(\mathrm{R}^{2}\right)$ for the Gross Regional Domestic Product ( $\mathrm{LnPDRB}$ ) equation is 0.9918 , which means that the combination of explanatory variables (predetermined variables and endogenous variables) can explain the Gross Regional Domestic Product variation of $99.18 \%$, while the remaining $0.82 \%$ is explained by other variables outside the model. Household consumption (LnKNRT), foreign and domestic investment (LnPMAD), and the export of goods/services (LnEKS) have a positive and significant effect on Gross Regional Domestic Product. However, the open unemployment rate (LnJTPT) and the district/city minimum wage (LnUMR) have negatively and significantly affected Gross Regional Domestic Product.

The coefficient value of household consumption is 0.553028 , foreign and domestic investment is 0.026581 , and the largest coefficient value is the export of goods/services, which is 0.661463 . This means that a $1 \%$ increase in the export of goods/services will 
increase the Gross Regional Domestic Product by $0.661463 \%$ with the assumption of ceteris paribus. Increased exports will encourage increased domestic production. Increased production will encourage increased domestic economic activity in terms of production, consumption, and distribution. This of course will increase economic growth. The results of this study are in line with the research of Quy (2016) and Rambeli et al. (2016) where exports of goods/services and an increase in labor had a positive and direct impact on economic growth.

Table 1. Estimation results of the factors that influence inclusive economic growth in Yogyakarta.

\begin{tabular}{lcccc}
\hline \multicolumn{5}{c}{ Parameter coefficient } \\
\hline Variables & LnPDRB & LnJTPT & KMK & GIN \\
\hline Intercept & 1.350570 & 0.485506 & $140.7763^{*}$ & $-1.56772^{*}$ \\
LnPDRB & - & $-1.06964^{*}$ & $-5.82210^{*}$ & $0.330934^{*}$ \\
LnJTPT & $-0.28607^{*}$ & - & - & - \\
LnKNRT & $0.553028^{*}$ & - & - & $-0.32496^{*}$ \\
LnEKS & $0.661463^{*}$ & - & - & - \\
LnPMAD & $0.026581^{* *}$ & - & - & - \\
LnIMR & - & $1.990394^{*}$ & - & - \\
LnUMR & $-0.13812^{* *}$ & $-0.38486^{* *}$ & - & $0.121419^{*}$ \\
LnPDKP & - & - & $-1.68266^{*}$ & - \\
LnRLS & - & - & $-11.2566^{*}$ & - \\
\hline $\mathrm{R}^{2}$ & 0.9918 & 0.8746 & 0.9917 & 0.4889 \\
F-Stat & 706.16 & 72.10 & 1257.44 & 9.88 \\
Prob F-Stat & 0.000 & 0.000 & 0.000 & 0.000 \\
\hline *** significant at 1\%, $5 \%$. & & & &
\end{tabular}

This study also shows that a $1 \%$ increase in foreign and domestic investment can increase Gross Regional Domestic Product by $0.026581 \%$ with the assumption of ceteris paribus. Foreign and domestic investment can increase production capacity by increasing the capital stock, and increased production will increase Gross Regional Domestic Product. The results of this study are in line with Anwar (2017) and Nur et al. (2013) where foreign and domestic investment had a positive effect on economic growth.

The coefficient value for the district/city minimum wage is 0.13812 . This means that a $1 \%$ increase in the district/city minimum wage will reduce the Gross Regional Domestic Product by $0.13812 \%$ with the assumption of ceteris paribus. This result has followed the research of Xu et al. (2015) where the effect of wages on economic growth was divided into two sides. For workers, wages mean income, increased wages should stimulate consumption demand, and consumption enhancement can increase economic growth. At the same time, wages mean company costs, increased wages can increase production costs, reduce production efficiency, and this can hinder economic growth.

The open unemployment rate equation (LnJTPT) has a determination coefficient $\left(\mathrm{R}^{2}\right)$ of 0.8746 , which means that the explanatory variable can explain the variation that occurs in open unemployment by $87.46 \%$. As much as $12.54 \%$ is explained by other variables 
outside the model. Variable Gross Regional Domestic Product (LnPDRB) and district/city minimum wage (LnUMR) have negatively and significantly affected open unemployment rate, while imports of goods/services (LnIMR) have positively and significantly affected open unemployment rate.

The Gross Regional Domestic Product coefficient of 1.06964 means that an increase of $1 \%$ of Gross Regional Domestic Product will reduce the open unemployment rate by $1.06964 \%$ with the assumption of ceteris paribus. This is in line with Okun (1962) who stated that there was a negative relationship between economic growth and unemployment. The higher the unemployment rate, the lower the economic growth rate, and vice versa. With sufficiently high output growth, it can lower the unemployment rate to a very low level. This is consistent with the research of Dirgantoro et al. (2009); Sipahutar et al. (2016); Sukanto (2015) where economic growth can increase demand for labor and reduce the unemployment rate.

This research also shows that every $1 \%$ increase in district/city minimum wage can reduce open unemployment rate by $0.38486 \%$ with the assumption of ceteris paribus. In this case, an increase in wages can increase household consumption. The increase in household consumption will increase the production of goods/services, so that it will indirectly increase the demand for labor and reduce the unemployment rate through increasing household consumption. This study also shows that an increase in imports of goods and services by $1 \%$ will increase the open unemployment rate by $1.990394 \%$ with the assumption of ceteris paribus. An increase in imports of consumer goods will reduce demand for domestic products, a decrease in demand for domestic products will reduce production, therefore, this will have an impact on reducing labor.

The coefficient of determination $\left(R^{2}\right)$ for the poverty equation (KMK) is 0.9917 , which means that the explanatory variable in the poverty equation can explain the variation in poverty by $99.17 \%$, and the remaining variation of $0.83 \%$ is explained by other variables outside the model. Poverty has been negative and significantly affected by variables of Gross Regional Domestic Product (LnPDRB), per capita income (LnPDKP), and an average length of year of study (LnRLS).

The coefficient value of per capita income of 1.68266 indicates that an increase of $1 \%$ of income per capita will reduce the poverty rate by $1.68266 \%$ with the assumption of ceteris paribus. This is in line with research conducted by Lisna et al. (2013); Rindayati et al. (2007); Sulistyowati et al. (2017) where per capita income was negatively related to poverty. An increase in per capita income followed by an even distribution of income will reduce the number of poor people because the people with the lowest income level will also be raised along with an increase in per capita income.

The results of this study also show that a 1\% increase in Gross Regional Domestic Product will reduce the poverty rate by $5.82210 \%$ with the assumption of ceteris paribus. This is under the existing theory that economic growth which continues to increase will increase people's income. The increasing income of the community will reduce the level of poverty in the region. The results of this study are the same as research conducted by Wibowo (2014) where economic growth had a negative effect on poverty. In this study, it 
is also seen that an increase of $1 \%$ in the average length of year of study can reduce the poverty rate by $11.2566 \%$ with the assumption of ceteris paribus. These results are consistent with the research of Wirawan \& Arka (2015) where the average length of year of study had been a negative effect on poverty.

The determination value $\left(\mathrm{R}^{2}\right)$ for the income inequality equation (GIN) is 0.4889 , which means that the explanatory variable in the income inequality equation can explain the variation in income inequality by $48.89 \%$. The Gross Regional Domestic Product variable (LnPDRB) and the district/city minimum wages (LnUMR) have a positive and significant effect on income inequality. Meanwhile, the household consumption variable (LnKNRT) has a negative and significant effect on income inequality.

The district/city minimum wages coefficient value of 0.121419 means that a $1 \%$ increase in district/city minimum wages will increase income inequality by $0.121419 \%$ with the assumption of ceteris paribus. This is in line with the research by Prasetyo et al. (2013) and Sungkar et al. (2015) where an increase in labor income in the industrial sector (formal) will increase inequality. The increase in income in the formal sector causes the difference in labor income between the industrial sector (formal) and the agricultural sector to widen, so that this will lead to income inequality in society. The Gross Regional Domestic Product coefficient value of 0.330934 indicates that a $1 \%$ increase in Gross Regional Domestic Product will increase income inequality by $0.330934 \%$ with the assumption of ceteris paribus. This is consistent with the research by Wahyuni et al. (2014) where economic growth has a positive effect on income inequality. This study also shows that a $1 \%$ increase in household consumption will reduce income inequality by $0.32496 \%$ with the assumption of ceteris paribus. This result is in line with the research of Fithrian et al. (2015) where consumption has a negative relationship with income inequality.

\section{Policies to increase inclusive economic growth in Yogyakarta}

Policies to increase inclusive economic growth in Yogyakarta are formulated based on variables that affect inclusive economic growth, namely the value of foreign and domestic investment (LnPMAD), household consumption (LnKNRT), and district/city minimum wage (LnUMR). These three variables are simulated by performing shocks using the average value of the growth period from 2011 to 2017 in Yogyakarta Province. Model validation and simulation were carried out using software (SAS/ETS) version 9.4 which used a non-linear simulation procedure (SIMNLIN) and the Newton method based on the statistical criteria of Root Mean Squares Percentage Error (RMSPE) and Theil's Inequality Coecient (U Theil) (Pindyck and Rubinfeld, 1997).

The model can be simulated. This is because the results of the analysis of the validation of the inclusive economic growth model obtained the RMSPE value of all endogenous variables below $15 \%$ and the overall $U$-Theil value below 0.1 , and the predicted value of each endogenous variable did not deviate from its actual value. The simulation results are shown in Table 2. 
Table 2. Policies to increase inclusive economic growth in Yogyakarta.

\begin{tabular}{lrcrrr}
\hline \multicolumn{1}{c}{ Variable } & Basic & Unit & \multicolumn{3}{c}{ Change (\%) } \\
\cline { 4 - 6 } & Value & & S1 & \multicolumn{1}{c}{ S2 } & \multicolumn{1}{c}{ S3 } \\
\hline Gross Regional Domestic Product & 14001849.70 & Million Rp & -0.3 & 0.4 & 1.5 \\
Open Unemployment Rate & 12533.74 & Person & -4.5 & -0.7 & -3.0 \\
Poverty & 15.33 & $\%$ & 1.8 & -2.4 & -10.7 \\
Income Inequality & 0.38 & Gini Index & 25.3 & 5.2 & -5.5 \\
\hline
\end{tabular}

Sources: Result of output SAS/ETS

The $\mathrm{S} 1$ simulation is an increase in the district/city minimum wage by $8.5 \%$. The simulation results show that an increase in the minimum wage of $8.5 \%$ will lead to a decrease in the Gross Regional Domestic Product of $0.3 \%$, which results in a decrease in the open unemployment rate of $4.5 \%$, but poverty and inequality increase by $1.8 \%$ and $25.3 \%$. S2 simulation increases foreign and domestic investment by $12 \%$. An increase in foreign and domestic investment by $12 \%$ will increase Gross Regional Domestic Product by $0.4 \%$, reduce open unemployment rate and poverty by $0.7 \%$ and $2.4 \%$, but inequality will increase by $5.2 \%$. In S3 simulation, an increase in household consumption by $2 \%$ will have an impact on an increase in Gross Regional Domestic Product by $1.5 \%$, but will reduce open unemployment rate, poverty, and inequality by $3.0 \%, 10.7 \%$, and $5.5 \%$ (Table 2 ).

The simulation results show that the policies of increasing the district/city minimum wage in the province of Yogyakarta can only reduce the open unemployment rate, but have not been able to increase Gross Regional Domestic Product and reduce poverty and income inequality. Foreign and domestic investment policies can reduce the level of open unemployment rate and poverty through increasing Gross Regional Domestic Product, but have not been able to reduce the level of inequality. Inequality can be reduced through policies to increase household consumption. An increase in household consumption by $2 \%$ has a direct impact on reducing inequality by $5.5 \%$ and indirectly reduces open unemployment rate by $3.0 \%$ and poverty by $10.7 \%$ through an increase in Gross Regional Domestic Product.

\section{CONCLUSION}

Based on the analysis, the policies of increasing the district/city minimum wage in Yogyakarta Province can only reduce the open unemployment rate, but have not been able to increase Gross Regional Domestic Product and reduce poverty and income inequality. Foreign and domestic investment policies can reduce the level of open unemployment rate and poverty through increasing Gross Regional Domestic Product, but have not been able to reduce the level of inequality. Inequality can be reduced through policies to increase household consumption. An increase in household consumption by $2 \%$ has a direct impact on reducing inequality by $5.5 \%$ and indirectly reduces open unemployment rate by $3.0 \%$ and poverty by $10.7 \%$ through an increase in Gross Regional Domestic Product.

The suggestion from this research is that local governments can encourage household consumption through tax reduction policies managed by the regions. A decrease in tax will 
Jurnal Economia, 16(2), October 2020, 200-210

cause disposable income to rise, so that household consumption increases. Local governments can also provide subsidies or social assistance to increase household consumption.

\section{REFERENCES}

Alekhina, V., \& Ganelli, G. (2020). Determinants of Inclusive Growth in ASEAN. IMF Working Papers, 20(118), 1-39. https://doi.org/10.5089/9781513549194.001

Ali, I., \& Son, H. H. (2007). Defining and measuring inclusive growth: Application to the Philippines. ERD Working Paper Series, 98, 1-44.

Ali, I., \& Zhuang, J. (2007). Inclusive growth toward a prosperous Asia: Policy implications. ERD Working Paper Series, 97, 1-44.

Anand, R., Mishra, S., \& Peiris, S. J. (2013). Inclusive Growth: Measurement and Determinants. IMF Working Paper, 13(135), 1-26.

Anwar, A. (2017). Peran Modal Manusia Terhadap Pertumbuhan Ekonomi Regional di Jawa. Jurnal Economia, 13(1), 79-94.

Asian Development Bank (ADB). (2011). Key Indicators for Asia and the Pacific 2011 : Framework of Inclusive Growth Indicators, Special Supplement. Asian Development Bank.

Azwar. (2016). Pertumbuhan Inklusif Di Provinsi Sulawesi Selatan Dan Faktor-Faktor Yang Mempengaruhinya. BPPK, 9(2), 216-242.

Badan Pusat Statistik. (2018). Daerah Istimewa Yogyakarta Dalam Angka 2018. Badan Pusat Statistik Propinsi D.I. Yogyakarta.

Dirgantoro, M. A., Mangkuprawira, S., Siregar, H., \& Sinaga, B. M. (2009). Dampak kebijakan desentralisasi fiskal terhadap transformasi ekonomi di provinsi jawa barat. Organisasi Dan Manajemen, 5(1), 1-9.

Fithrian, M., Syechalad, N., \& Nasir, M. (2015). Analisis Pengaruh Aggregat Demand Dan Tingkat Pendidikan Terhadap Ketimpangan Pendapatan Di Aceh. Ilmu Ekonomi Pascasarjana Universitas Syiah Kuala Mementingkan, 3(3), 23-32.

Gujarati, D. N., \& Porter, D. C. (2010). Essentials of Econometrics Fourth Edition (4th ed.). McGraw-Hill.

Klasen, S. (2010). Measuring and monitoring inclusive growth in developing and advanced economies: Multiple definitions, open questions and some constructive proposals. Reframing Global Social Policy: Social Investment for Sustainable and Inclusive Growth, 12, 123-144.

Lee, N., \& Sissons, P. (2016). Inclusive growth? The relationship between economic growth and poverty in British cities. Environment and Planning A, 48(11), 2317-2339. https://doi.org/10.1177/0308518X16656000

Lisna, V., Sinaga, B. M., Firdaus, M., \& Sutomo, S. (2013). Dampak Kapasitas Fiskal terhadap Penurunan Kemiskinan: Suatu Analisis Simulasi Kebijakan. Jurnal Ekonomi Dan Pembangunan Indonesia, 14(1), 1-26. https://doi.org/10.21002/jepi.v14i1.433 
McKinley, T. (2010). Inclusive growth criteria and indicators: an inclusive growth index for diagnosis of country progress. Asian Development Bank Working Paper, 14, 1-34.

Munir, F., \& Ullah, S. (2018). Inclusive Growth in Pakistan: Measurement and Determinants. The Pakistan Journal of Social Issues, Special Issue, 150-162.

Nur, I., Mulatsih, S., \& Asmara, A. (2013). Analisis Struktur Perekonomian Dan FaktorFaktor Yang Memengaruhi Pertumbuhan Ekonomi Sumatera Selatan. Jurnal Ekonomi Dan Kebijakan Pembangunan, 2(1), 47-59. https://doi.org/10.29244/jekp.2.1.47-59

Okun, A. M. (1962). Potential GNP: its measurement and significance. In Proceedings of the Business and Economic Statistics Section of the American Statistical Association. American Statistical Association (pp. 98-104).

Pindyck, R. S., \& Rubinfeld, D. L. (1997). Econometric models and economic forecasts (4th ed.). McGraw-Hill.

Prasetyo, B. A., Priyarsono, D. S., \& Mulatsih, S. (2013). Infrastructure, Economic Growth, And Inequality In Indonesia Land Borders. Economic Journal of Emerging Markets, 5(2), 99-108.

Quy, N. H. (2016). Relationship between Economic Growth, Unemployment and Poverty: Analysis at Provincial Level in Vietnam. International Journal of Economics and Finance, 8(12), 113-119. https://doi.org/10.5539/ijef.v8n12p113

Rambeli, N. B., Marikan, D. A. A., \& Hashim, E. (2016). The Effect of Foreign Direct Investment, Exports and Employment on Economic Growth Model. International Journal of Academic Research in Business and Social Sciences, 6(11), 361-376. https://doi.org/10.6007/ijarbss/v6-i11/2405

Rindayati, W., Hutagaol, M. P., \& Siregar, H. (2007). Dampak Desentraliasai Fiskal Terhadap Kinerja Fiskal Daerah Dan Ketahanan Pangan Di Wilayah Provinsi Jawa Barat. Jurnal Manajemen Dan Agribisnis, 4(2), 103-117.

Satrio, M. K., Amar, S., \& Aimon, H. (2019). Determinants of Inclusive Growth on the Inequality. Advances in Economics, Business and Management Research, 97(Piceeba), 138-148. https://doi.org/10.2991/piceeba-19.2019.17

Sholihah, D. H. A., Hutagaol, M. P., \& Asmara, A. (2018). Pertumbuhan Inklusif: Fenomena Pertumbuhan Inklusif Di Kawasan Indonesia Bagian Barat Dan Indonesia Bagian Timur. Jurnal Ekonomi Dan Kebijakan Pembangunan, 2(2), 85-112. https://doi.org/10.29244/jekp.2.2.85-112

Sipahutar, M. A., Oktaviani, R., Siregar, H., \& Juanda, B. (2016). Effects of Credit on Economic Growth, Unemployment and Poverty. Jurnal Ekonomi Pembangunan: Kajian Masalah Ekonomi Dan Pembangunan, 17(1), 37-49. https://doi.org/10.23917/jep.v17i1.1651

Sukanto, S. (2015). Fenomena Inflasi, Penganguran Dan Pertumbuhan Ekonomi Di Indonesia: Pendekatan Kurva Philips Dan Hukum Okun. Jurnal Ekonomi Pembangunan, 13(2), 96-106. https://doi.org/10.29259/jep.v13i2.4859

Sulistyowati, N., Sinaga, B. M., \& Novindra, N. (2017). Impacts of Government and Household Expenditure on Human Development Index. Jejak, 10(2), 412-428. https://doi.org/10.15294/jejak.v10i2.11305 
Jurnal Economia, 16(2), October 2020, 200-210

Sungkar, S. N., Nazamuddin, \& Nasir, M. (2015). Pengaruh Upah Minimum Terhadap Ketimpangan Pendapatan Di Indonesia. Jurnal Ilmu Ekonomi, 3(2), 40-53.

Wahyuni, I. G. A. P., Sukarsa, M., \& Yuliarmi, N. (2014). Pengaruh Pengeluaran Pemerintah Dan Investasi Terhadap Pertumbuhan Ekonomi Dan Kesenjangan Pendapatan Kabupaten/Kota Di Provinsi Bali. E-Jurnal Ekonomi Dan Bisnis Universitas Udayana, 3(8), 91-101.

Wibowo, D. A. (2014). Pengaruh Pembiayaan Pendidikan, Tingkat Pendidikan, Pertumbuhan Ekonomi Dan Kemiskinan Di Jawa Tengah. Jurnal Economia, 10(2), 133-140. https://doi.org/10.21831/economia.v10i2.7539

Wirawan, I. M. T., \& Arka, S. (2015). Analisis Pengaruh Pendidikan, PDRB Per Kapita Dan Tingkat Pengangguran Terhadap Jumlah Penduduk Miskin Provinsi Bali. EJurnal EP Unud, 4(5), 546-560.

World Bank. (2018). Riding the wave An East Asian Miracle for the 21st Century. World Bank East Asia and Pacific Regional Report. In World Bank. World Bank.

Xu, S., Huo, L., \& Shang, W. (2015). The impact of wage distributions on economic growth based on multi-agent simulation. Procedia Computer Science, 55(Itqm), 809-817. https://doi.org/10.1016/j.procs.2015.07.155 